\title{
Foolishness, Stupidity, AND Cognitive Values
}

\section{Introduction}

What are the relations between ethical values and moral norms, on the one hand, and cognitive values and norms, on the other hand? Between ethical and intellectual virtues and vices? Between cognitive values and other types of value-aesthetic, hedonic, political, prudential and religious? Between kitsch, sham emotions or sentiments, and foolishness? Between foolishness and cognitive vices and forms of practical irrationality such as self-deception, ressentiment, blether, obscurantism, and obscurity? What are and should be our affective attitudes towards knowledge, truth, justification, precision, and clarity?

In 1930 José Ortega y Gasset wondered why there is still no study of foolishness (tonteria) dealing with those aspects of the phenomenon not investigated by Erasmus. ${ }^{1}$ The first installments of The Man Without Qualities in 1931 and 1933 provide a remarkable panoply of fools, foolishness, silliness, and stupidity and a determined attempt to understand these phenomena. The passion of the book is, its author says, the passion for precision. ${ }^{2}$ Reason, he also says, "plays a great role" in his art. ${ }^{3}$ Many of the fools and follies in the novel are presented as examples of attempts to adapt mind (Geist) to life. The Parallel Action is, through and through, a foolish enterprise. ${ }^{4}$ Arnheim, Meingast, Feuermaul, Hans Sepp, Gerda, Diotima, Bonadea, Clarissa, and Professor Lindner display a variety of cognitive vices. Humanitarianism, intuition, mindless action or energy, and pharisaism are depicted as cognitive vices or evils.

Ulrich and Agathe, on the other hand, are (imperfect) epistemic heroes. Agathe has "an unusually exact memory, which did not deform its contents by any sort of prejudice or wishful thinking." the (Weiningerian?) narrator, although intelligent women such as Agathe are "unerring in their observation of the men they love," they have no theoretical inclinations. ${ }^{6}$ Unlike Ulrich, who is a prince of mind. Ulrich listens 
to, analyses, evaluates, and indeed provokes an astonishing amount of nonsense and bullshit. Thus "Ulrich converses with Hans Sepp and Gerda in the pidgin-language of the frontier district between the super-rational and the sub-rational." What Sepp has to say is mere nonsense, claptrap (Geschwätz), peppered with pretentious nouns. ${ }^{7}$

One early striking appearance of foolishness in the novel is the account given by Ulrich and the narrator of a peculiar phenomenon-the tendency of the cognitively virtuous to manifest this virtue or habit only in severely restricted contexts. Ulrich's second career, as an engineer, fills him with enthusiasm because of its possibilities:

Who still needed the Apollo Belvedere when he had the new forms of a turbodynamo ... before his eyes !... Looked at from a technical point of view, the world is simply ridiculous: impractical in all that concerns human relations, and extremely uneconomic and imprecise in its methods; anyone accustomed to solving his problems with a slide-rule cannot take seriously a good half of the assertions people make ... If you own a slide-rule and someone comes along with big statements or great emotions, you say: "Just a moment, please-let's first work out the margin for error and the most probable values." 8

But "this powerful view of what it meant to be an engineer" is not shared by the engineers Ulrich has known, who fail to "adapt the daring and innovative soul of [their] technology to [their] private soul[s]": 9

It is hard to say why engineers don't quite live up to this vision ... [A]ny suggestion that they might apply their daring ideas to themselves instead of their machines would have taken them aback, much as if they had been asked to use a hammer for the unnatural purpose of killing a man. ${ }^{10}$

Their cognitive virtues or habits, then, are manifested only selectively.

The panoply of folly presented in the novel is contrasted in many ways with the first and third of the three individual utopias explored one after the other in the novel-the utopia of exactness and the utopia of inductive humility. And these contrasts cannot be understood without understanding the relation between the two epistemic utopias ${ }^{11}$ and the second utopia, of the other condition (state). Musil's account of foolishness is by no means restricted to his novel. It is everywhere in his essays, addresses, and other writings. In 1937 Musil published "On Stupidity" ("Über Dummheit"), which is based on a lecture given in the same year in Vienna. The number of his contemporaries writing and speaking for and 
against Fascism, Bolshevism, and democracy is legion. Musil, however, turns his attention to foolishness. ${ }^{12}$ The publication of this essay in fact marks the end of a decade of intensive investigation of cognitive values and disvalues by a small but select group of thinkers.

The decade begins with the publication in 1927 by Julien Benda of La Trahison des clercs (The Treason of the Clerisy), a treason due to the "desire to abase the values of knowledge before the values of action."13 It continues with the appearance in 1930 of Ortega's La Rebelión de las Masas (The Revolt of the Masses). It continues with publications by Ernst Robert Curtius, Nicolai Hartmann, Heinrich Gomperz, and Husserl's pleas for a "heroism of reason." The philosophical enemies of Husserl and Hartmann, the logical positivists and the logical empiricists, are also fascinated by cognitive values. Throughout the decade Bertrand Russell and the only French member of the Vienna Circle, Louis Rougier, return again and again to a variety of cognitive vices.

Musil's views about cognitive values are bound up with almost all his other views about how we do, could, might, would, or should live. Many of these views are couched in now unfamiliar terms. This is particularly true of his versions of such Austrian chestnuts as atheist or profane mysticism and the claim that the ethical is aesthetic. But it is also true of his meditations on the relations between possibilities, probabilities, and life and his account of ideals. Even those parts of his views which resemble currently popular or familiar views, such as his distinction between ethics and morality and his ethical particularism and contextualism, have unfamiliar dimensions. In what follows I examine some of the main aspects and strata of Musil's account of foolishness. It will unfortunately not be possible to consider his explorations of the relations between foolishness and, for example, panic, culture, enthusiasm (Schwärmerei), vanity, amour propre, music, false feelings, hollow feelings, kitsch, sentimentality, intuitionism, literalism, and irony. ${ }^{14}$

\section{Pan-Romantic Follies}

One predecessor of the accounts and defenses of cognitive values published between 1927 and 1937 is the identification by Max Scheler of a misological German tendency he called Pan-Romanticism and his criticisms of this movement. The principal Pan-Romantic is the German graphologist, ecologist, and philosopher, Ludwig Klages, one of the forgotten grandfathers of contemporary Continental Philosophy. The German 
businessman and philosopher, Walther Rathenau, is also part of the tendency, as is, for the most part, Oswald Spengler. Two other objects of Scheler's criticisms are the German pacifist, pedagogue, and progressive philosopher Wilhelm Förster and Expressionism.

Musil, who notes very early that the philosophy of Rathenau belongs to a "neo-romantic" trend, criticizes in great detail the irrationalisms of Rathenau and Spengler. But his most striking anatomies of misology are his explorations of the minds and lives of Arnheim, Meingast, Feuermaul, and Prof. Lindner in his novel. The model for Arnheim is Rathenau; for Meingast, Klages; for Feuermaul, the Expressionist poet from Prague and kitsch counterpart of Rilke, Franz Werfel; for Prof. Lindner, Förster.

Pan-Romanticism, a descendant not only of Romanticism but also of the philosophy of life of Nietzsche, opposes mind (Geist) to life, and sees the latter as a victim of the former. Mind, that is to say, the will and the intellect, oppresses life, the soul and, in particular, the heart. Mind (Geist) and soul (Seele) are, then, very different things. Intellect, understanding, calculation, and the will are bad. The soul, emotions, feelings, and intuitions are good. Pan-Romanticism is, Scheler thinks, a specifically German disease:

This strange theory ... turns out to be a strict logical consequence if one ... distinguishes Geist, or reason, and life as two ultimate metaphysical agents, but identifies life with soul and Geist with technical intelligence and-and this is decisive-makes vital values into the highest values ... Geist is then a demon, yes-the Devil, the power which destroys life and soul ... Geist appears as a metaphysical parasite which bores into life and soul in order to destroy them. ${ }^{15}$

Scheler quotes one of the leading pan-romantics, Theodor Lessing:

... my basic thought ... [is] that the world of Geist and its norm is no more than the indispensable Ersatz-world of life which has become sick because of man, merely the means of saving a species of predatory ape [Raubaffe] ... gone mad because of science. ${ }^{16}$

Scheler and Musil reject both the evaluative claims behind this twentiethcentury Rousseauism and also the conception of mind it employs. It is a widespread theoretical mistake, they think, to exclude affectivity from the mind. And it is a normative mistake to place the value of life higher than that of Geist. (Their versions of these mistakes are not, of course, identical.) They are also both very critical of the intuitionisms and irrationalisms which these mistakes encourage. Indeed they say that they are involved in 
a struggle against the revivals of Romanticism. ${ }^{17}$ Musil's interrogations of these revivals and related doctrines take very seriously a question asked by Nietzsche and William James: what happens when people live according to a philosophy?

Consider, for example, Arnheim, a "man of reality" (Wirklichkeit). ${ }^{18}$ Whereas Ulrich is a "prince of Geist," Arnheim

is not a prince of Geist, but a great man of letters ... The great man of letters has replaced the prince of Geist ... He is a particular form of the connection between Geist and great things. ${ }^{19}$

And "there is nothing so dangerous for Geist as its involvement with great things." ${ }^{20}$ Arnheim thinks of Ulrich as a "brilliant" (geistvollen) man who is unable to

recognize the advantages life offers and to adjust his Geist to the great objects and opportunities that would bring him status and a solid footing in life. Ulrich manifested the absurd contrary conviction that life had to adapt to Geist. ${ }^{21}$

One way in which Geist adapts itself to life is through the cognitive vice of self-deception. Arnheim's confrontation with Ulrich leads him into self-deception:

Arnheim took it for granted that he could find a way to neutralize his opponent. But he wanted to win Ulrich over, to influence him, teach him, compel his admiration. In order to make this easier, he had talked himself into feeling a deep and paradoxical affection for Ulrich, though he would not have known how to account for this. ${ }^{22}$

Arnheim's self-deception involves a fake feeling, a make-believe sentiment, what Stendhal calls an "amour de tête." Its starting point is not just "the decision to get Ulrich into his power" but a failure to admit something:

Ulrich, in his antagonism, had at last succeeded in touching Arnheim to the quick ... [Arnheim] admitted to himself that nothing of this sort had happened to him for a long time. The usual methods by which he achieved success were of no avail here. For the effect a great and integral man has is like the effect of beauty: it can no more stand up to a denial of its existence than a balloon can stand up to having holes drilled into it ... Not that Amheim confessed as much to himself in these words, but he did think...

-a superb example of what pass for thoughts in an enemy of Geist- 
"I cannot endure contradiction, because it is only the intellect [Verstand] that thrives on contradiction, and I despise anyone who possesses only intellect!"23

Arnheim's self-deceptions are by no means limited to his relations to Ulrich. His attachment to soul is such that, like Rathenau, he uses the word "Seele" in his writings "like a method, a flying start, as a sovereign term":

But what was questionable and uncertain was whether Arnheim, when he spoke of the soul, himself believed in it and ascribed to the possession of a soul the same reality as to his own possession of stocks and shares. He used it as a term for something for which he had no other term. ${ }^{24}$

The inseparability of form and content is not merely a mark of successful verbal art. It may also be a symptom of language on holiday, of philosophical nonsense, as in the case of "Seele" and its meaning for Rathenau/ Arnheim. Such nonsense is at the heart of Rathenau's central self-deception. Arnheim's Geist is all humbug:

There was a con game [Schwindel] in this union between the soul and the price of coal, a union that at the same time purposefully served to keep apart what Arnheim did with his eyes open and what he said and wrote in a cloud of intuition. ${ }^{25}$

Arnheim's self-deceptions are the result of adapting Geist to life. They are made up of make-believe sentiments and make-believe beliefs which function in his life like sentiments and beliefs. Franz Blei, ${ }^{26} \mathrm{a}$ friend to Musil, Scheler, and Rathenau, quotes (incorrectly) as the most striking (das Treffendste) thing Musil says about Rathenau the following passage about Arnheim:

And it is equally certain that his ambition to master all there was to be known ... found in the soul a means of devaluing everything that his intellect could not master. For in this he was not different from his whole era, which had newly developed a strong religious tendency, not as the result of any religious destiny [Bestimmung, vocation] but merely, as it seems, out of a feminine and irritable rebellion against money, knowledge, and calculation, to all of which it passionately succumbed. ${ }^{27}$

The mechanism Musil describes here is that of ressentiment or sour grapes-"devaluing" (entwerten) something in order to make life more agreeable. Arnheim's self-deceptions and his ressentiment are two of the most fundamental features of his irrationality. 
We have seen that Arnheim thinks Ulrich is unable to recognize the advantages life offers and to adjust his Geist to the great objects and opportunities that would bring him a solid footing in life. This failure is "part of what Arnheim means" by what he calls Ulrich's wit (Witz). ${ }^{28}$ "All his life, Arnheim had felt an almost morbidly sensitive dislike of wit and irony." 29 Arnheim's self-deceptions and his dislike of wit and irony are two of the components of the deep existential envy or jealousy Ulrich provokes in Arnheim. ${ }^{30}$ Irony is, of course, the appropriate reaction to foolishness. ${ }^{31}$

Arnheim is one among many to whom Ulrich's strictures, formulated just before he puts forward his "preposterous" proposal to found a World Secretariat for Precision and Soul, apply:

... those who feel called upon to act, in order to restore some meaning to life, have one thing in common: they despise 'mere' thinking just at the point where it could lead us to truths rather than simple personal opinions; instead, where everything depends on pursuing those views to their inexhaustible wellspring, they opt for shortcuts and half-truths. ${ }^{32}$

The analysis of the follies of Arnheim (and other characters) and their relation to Pan-Romanticism are, as we shall now see, merely the surface of the anatomy of foolishness in Musil's novel.

\section{Normative Minimalism and the Rejection of Ideals}

Two of the most important parts of Musil's reflections about normative matters are his use of a distinction between ethics and morality and his criticisms of ideals. (Others are his contextualism, his particularism, his distinctions between what is good tout court, good-good and good-bad as well as his philosophy of possibility and probability.) They are both intimately bound up with his understanding of foolishness. Like such recent philosophers as Bernard Williams and earlier philosophers such as Nietzsche, Meinong, and Scheler, Musil distinguishes sharply between ethics and morality. In 1922 he traces "a boundary between ethics and morality" as follows:

In accordance with its prescriptive nature, morality is tied to experiences that can be replicated, and these are precisely what characterize rationality as well, for a concept can only take hold in areas where explicitness and, figuratively speaking, replicability obtain. Thus there exists a profound connection between the civilizing character of morality and of the scientific spirit, whereas 
the truly ethical experience, such as love, searching one's heart, or humility, is, even where it is of a social nature, something difficult to transmit, something quite personal and almost anti-social ... What passes for ethics in our current literature is for the most part a narrow foundation of real ethics, with a skyscraper of morality above it. ${ }^{33}$

In 1913 Musil had summed up the categorical imperative in an essay which distinguishes between two types of morality rather than ethics and morality:

The categorical imperative, and what has counted since as specifically moral experience, is at bottom nothing but a grumpily dignified scheme [eine bärbeissig würdige Intrige] to return once again to feeling. But this forces into the foreground something entirely secondary and dependent, which assumes moral laws instead of creating them; an auxiliary experience of morality, and by no means its central experience. ${ }^{34}$

In a note on the morality of Anders, Ulrich's predecessor, Musil writes:

Act in such a way that your acting can be a recipe [Rezept] for everyonethis Kantian morality is the German morality, is conscientiousness personified.

And opposes to it Anders's view:

Do not act so that your acting is a recipe for everyone, but so that it is valuable. Where "value" comes from the sphere of the other state, is that indefinable "living" movement. ${ }^{35}$

In 1914 he says that in the other condition there "is no ethical [ethisches] action but only an ethical state, within which an immoral [unsittliches] activity or way of being is impossible." 36 Thus Musil distinguishes between ethical values and moral rules or laws, but also between morality which reflects or derives from ethical values and morality which does not have this feature. Ethical value or "value" is associated above all with the other condition, the different states of felicity or beatitude [Seligkeit] —erotic, aesthetic, and mystical. ${ }^{37}$

These distinctions and claims are the background to the plea for what might be called moral minimalism:

It would be a useful experiment to try to cut down to the minimum the moral expenditure (of whatever kind) that accompanies all our actions, to satisfy ourselves with being moral only in those exceptional cases where it really 
counts, but otherwise not to think differently from the way we do about standardizing pencils or screws. ${ }^{38}$

In a world where morality is minimal "the washed-out prints that develop from the pallid resemblance of actions to virtues would disappear from the image of life." 39 Moral minimalism may be justified in many different ways. On some views of virtue a morally virtuous person typically manifests his virtues automatically. Similarly, one might think that political conservatism-as opposed to conservatism tout court-requires moral minimalism. Moral minimalism also recommends itself for the same sort of aesthetic reasons that all forms of minimalism recommended themselves to so many modernist Austrians-clean lines and the elimination of ornamentation are as important in life as in architecture. But Musil presents moral minimalism as a way of living "with precision." 40 What does this mean? His justification of moral and, more generally, normative minimalism differs from those mentioned (without being incompatible with them). It is to be found in his critique of ideals.

In his 1921 essay "The Nation as Ideal and as Reality," Musil says of the way of thinking which takes seriously the ideal of the nation, particularly when the nation is conceived of in racial and collectivist terms, that it "produces the person who has fixed recipes and sublimely simple rules for everything, who puts himself above spiritual experience: the Pharisee." 41 The moral pharisee continually asks himself what his moral duty requires. The pharisee described by Musil, for whom the nation is an ideal, considers everything from the point of view of the realization or nonrealization of his ideal. The results, Musil thinks, are a series of cognitive vices, failures, and bad habits: "a diseased way of thinking"; "truthfulness and intellectual refinement become dulled"; "all the germ cells of morality degenerate":

When virtue is declared to be national property by predestination, the Lord's vineyard is expropriated and no one needs to work in it any more. The individual is flattered into believing that he possesses everything desirable by merely contemplating the virtues of his "race." 42

Musil describes a "lack of respect for the mind (Geist) in the name of the German Spirit (Geist)":

Broad circles of our people - and one is almost inclined to say the ones with the best intentions-have lost the ability to judge an achievement by its substance; they test it only according to its origins, and thereafter as it fits into their 
system of prejudices. The broadest is measured by the narrowest, the versatile mind by one of its stillbirths. Attention has turned away from values to their accompanying circumstances, from reality to hypothesis, and those who are called upon to follow have been seized by a sectarian arrogance and preaching. ${ }^{43}$

The ethico-political ideal of the nation engenders and is the result of cognitive vices. Musil's target however is not only the ideal of the nation but the ideal of the nation. His view is that the ideal of the nation is a bad thing because ideals are bad things: "ideals are the worst enemies of idealism. Ideals are dead idealism, decaying remains [Verwesungsrückstände]" says Thomas in Die Schwärmer. ${ }^{44}$ Indeed "[i]deals and morality are the best means for filling that big hole called soul." 45

Musil's criticisms of ideals resemble those of Nietzsche and, for example, Ibsen and Shaw. ${ }^{46}$ Views of this kind are by no means common within contemporary normative philosophy, although they are to be found wherever Nietzsche and Spinoza are taken seriously. The rejection of ideals as pharisaical amounts to the claim that the most popular kinds of normative ethics are pharisaical. In order to see what is involved here we should distinguish different claims about pharisaism. There are different kinds of pharisaism corresponding to the different families of normative concepts. There is the pharisaism of ethical goodness where the ideal is to be ethically good (the "Unco Guid" of Robert Burns's poem, "Holy Willie's Prayer"). There is deontic pharisaism-the ideal is my moral duty. There is aretaic pharisaism, the pharisaism of virtue and, finally, the pharisaism of moral and political right and wrong-righteousness or political correctness. In each case pharisaism requires a first-person perspective: I am concerned with my ethical or moral value, duty, virtue, etc. And of course, the first-person perspective may be a plural egotistical perspective. With respect to each form of pharisaism we may distinguish a strong (Max Scheler) and a weak claim (Nicolai Hartmann). The strong claim is that it is always ethically a bad thing to take one's relation to such ideals seriously-for example, to ask oneself what one's moral duty requires. The weak claim is that doing this too often is a bad thing. Another weakening of the strong claim restricts the epithet of pharisiaism to, say, deontic moral ideals. Musil's reflections about ideals are not sufficiently detailed for it to be possible to pin him down about pharisaism. But there can be little doubt of the importance he attached to identifying and criticizing the reliance on ideals. His explanation of the outbreak of the Great War, like that given by Shaw, refers to ideals. ${ }^{47}$ 
The category of ideals is closely linked to two other frequent targets of Musil's irony and satire: great things and Seinesgleichen geschieht ("Pseudoreality prevails," "The like of it happens"). We have already noted the importance of great things for a very intelligent fool such as Arnheim. One of Musil's most nastily accurate remarks about the "great" man of letters, Thomas Mann, is that he turns all his experiences into categorical imperatives. Amongst the many things one does because "one" does them is to behave in such a way that one realizes and fails to realize ideals which continually hover before one's mind:

But the minute a soul has morals, ... ideals in the spheres of duty and beauty, it has been equipped with a system of rules ... that it must obey before it can think of being a respectable soul. ${ }^{48}$

What is Musil's alternative to the ideals one looks up to and occasionally lives up to, to the method "which admittedly kills the soul but then, so to speak, preserves it for general consumption by canning it in small quantities"? The method is adopted out of fear. One "takes refuge from the impossibility of living constantly in [a] fire by beginning to live for the fire . . ." ${ }^{49}$ Musil contrasts living for an ideal and living in something: ". . . a great difference: to live for something or to live in something!" 50 for example, living for religion and living in a religious state, living religiously. ${ }^{51}$ Living In is life in the other condition or life which approximates to it or takes it seriously. The idea of living In is closely related to what Musil also calls living essentially and a motivated life. The already mentioned "hole," which is brimming over with ideals, prevents any sort of life In:

I attempt to show what I call the "hole in European morality," . . because it prevents right action: it is, in brief, the false treatment which has been accorded to mystical experience. ${ }^{52}$

Lindner, Schmeisser, and Meingast are "For-Men" (Für-Männer) as is Hagauer. ${ }^{53}$ Nor are they the only such men in the novel. But Musil's most vivid account of what it is to live for an ideal is his portrait of Prof. Lindner, the "Tugut" or do-gooder. ${ }^{54}$ Already in 1914 Musil notes that the idea that "good works in this world somehow constitute our existence in the next" has become a favorite idea of spiritualist philosophy. ${ }^{55}$ Dogooders, where the relevant type of goodness is ethical goodness, what is 
often (although not by Musil) opposed to evil, are deontic Pharisees: "Lindner transformed absolutely everything he came into contact with into a moral imperative ..."56 just like (Musil's) Thomas Mann, and all those who "turn a condition into an imperative, a state of grace into a norm, a state of being into a purpose." 57 Lindner lives as "one" lives and is supposed to live: his remarkable inclination to subject himself to a daily "regime" "is a result of the movement toward the worker-warrior-anthill state toward which the world is moving." 58 His mental life is dominated by ideals: ". . . there hovered before him as an ideal for the world a community of fully responsible moral personalities . . ." ${ }^{59} \mathrm{He}$ is one of the right-minded (Gutgesinnten) of those who "descend from the unimportant to the trivial without noticing a difference" 60 _not by any means an ethical vice. He is, Musil writes in his notes, an "example of a man who lives For and is afraid of living In." 61

Living In stands to living For as being good to doing good. Ulrich seems to accept that "the good will is not to will the good but to will in goodness." 62 Agathe applies the lessons she has learned from Ulrich to Hagauer:

Well, perhaps it was rather that [Hagauer] was one of those people who always do the good thing; they themselves have no goodness in them, Agathe thought. It seems that goodness disappears from the human being to the same extent that it is embodied in goodwill or good deeds! ${ }^{63}$

Living for an ideal is an ethical error. To live for an ideal is to be blinded by fear. As we have seen, Lindner is "afraid" of living In, one "takes refuge from" the impossibility of living constantly in by beginning to live for. More generally, living for is a pretext which is advantageous. He who adopts ideals

fills the many moments of his day ... not with his ideal state but with the many ways of achieving it by overcoming obstacles and incidents-which guarantees that he will never need to attain it. ${ }^{64}$

But to live for ideals is also to be guilty of "rationalization" where this "new word" signifies self-deception, for one's beliefs to be bound up with the convictions one would like to have. "The fact is that people prefer wanting to be good, beautiful and sincere to being good, beautiful and sincere." 65 Such pharisaism is foolish and makes its sanctimonious victim more and more foolish: "that for which a person lives is a magnet, which 
grows larger and larger through that which it attracts. ${ }^{66}$ To the extent that normative ideals regularly hover before a person's mind these make him blind to the way the world really is. One who, faced with a drowning child, asks himself what his moral duty requires is blind to what is going on.

\section{Foolishness, Stupidity, and Interest}

Musil's 1937 address "Über Dummheit," which draws extensively on his novel, is his most direct and extended attempt to understand what he calls stupidity. He reflects on the use of "dumm" and related words. Like Wittgenstein and Bühler, and influenced by Klages's account of "Liebe," he thinks that some words are what have been called family resemblance terms ${ }^{67} \mathrm{He}$ also distinguishes two "very different" kinds of what he calls "Dummheit." The first kind is honest and straightforwardbased on "weakness of understanding," it is "a little dull of comprehension" and has a "dim wit"." It is "poor in ideas and words, and awkward in applying them;" it is slow. It is, we might say, whatever is measured by IQ tests. In the second kind, even "an undamaged innate intelligence" may be hindered, frustrated, and led astray by the most varied kinds of mental (geistige) and psychological (seelische) deviations. Musil does not think that the second kind of Dummheit is compatible with a lack of intelligence: "somewhat paradoxically, it is even a sign of intelligence." Unlike the first kind it is based "more on an understanding that is weak only with regard to some particular." Musil says that German has only one word for these two phenomena-"Dummheit."68 The distinction between the two might be marked in English by distinguishing between stupidity, understood as the absence of intelligence, something one is born with, which endures, and foolishness (Torheit, sottise), a vice or bad habit, which either endures or occurs.

Of the "higher, pretentious form of stupidity" Musil says that it

is not so much lack of intelligence as failure of intelligence for the reason that it presumes to accomplishments to which it has no right; and it can have all the bad characteristics of weakness of understanding, and in addition all those characteristics brought about by every heart [Gemüt] that is not in balance, that is misshapen and erratically active; in short, every heart that deviates from health. To put it more accurately: because there are no 'normalized' hearts, this deviation expresses an insufficient play of harmony between the one-sidedness of feeling and an understanding that is not strong 
enough to hold it in check. This higher stupidity is the real disease of culture [Bildungskrankheit] ... and to describe it is an almost infinite task. It reaches into the highest intellectual sphere [Geistigkeit] . . . Years ago I wrote about this form of stupidity that "there is absolutely no significant idea that stupidity would not know how to apply; stupidity is active in every direction, and can dress up in all the clothes of truth. Truth, on the other hand, has for every occasion only one dress and one path, and is always at a disadvantage." The stupidity this addresses is no mental illness [Geisteskrankheit], yet it is most lethal [lebensgefährlichste], the disease of Geist that endangers life itself. ${ }^{69}$

The example of Arnheim shows just how the higher form of stupidity can take on characteristics which are due to an erratically active heart. Musil's anatomy of its variety focuses on novel species of foolishness, those encouraged by neo-romantic philosophies which proclaim that mind is the enemy of life. According to Musil, foolish minds endanger life itself. Musil gives part of the explanation for the variety of foolishness, the fact that there is no significant idea to which foolishness cannot apply although foolishness itself is always camouflaged: "If it were not so hard to distinguish stupidity from talent, progress, hope, or improvement, no one would want to be stupid."70 As Aquinas says, "though no man wishes to be a fool, yet he wishes those things of which folly is a consequence."

What does Musil oppose to the second "intelligent" kind of stupidity? One answer, as we shall see, is: the significant, the valuable. In order to understand this curious formulation it is useful to consider the following objection to Musil. If ideals are a bad thing, are not cognitive ideals also a bad thing? At the end of a draft for a 1935 lecture in Paris, Musil mentions conditions for the rise of culture such as

freedom, openness, courage, incorruptibility, responsibility, and criticism, criticism even more against what seduces us than against what repels us. These concepts must even include the love of truth ... because what we call culture is not directly subservient to the criterion of truth; but no great culture can rely on a distorted relationship to truth. ${ }^{71}$

But, so the objection, if ethical ideals are a bad thing, are not ideals such as truth also a bad thing? Musil's alternative to the pharisaical proliferation of normative ideals which hover before the mind and fill up the soul is, as we have seen, a minimal morality which is anchored in the value of things like the other condition. What, then, stands to cognitive virtue or good cognitive habits as the other condition stands to morality? The answer 
suggested by Musil's novel is: interest and attention. Ulrich and the narrator of the novel display at all times an extraordinary degree, depth, urgency, and variety of interest and attention. Their interest and attention are directed towards a large variety of normative matters. Such interest and attention lie behind their will to know and to find out. Ulrich points out that, although many feelings are an obstacle to knowing, one group of feelings makes knowledge possible:

But knowing ... possesses a specific peculiarity in relation to the emotions that is easily perceived and characterized: in order to know we must put aside our emotions to the greatest extent possible. We block them out in order to be "objective," or we place ourselves in a state in which the abiding emotions neutralize each other, or we abandon ourselves to a group of cool feelings that, handled carefully, are themselves conducive to knowledge. We draw upon what we apprehend in this clear-headed condition for comparison when in other cases we speak of "delusions" through the emotions; and then we have a zero condition, a neutralized state: in short a specific state of the emotions, the silent presupposition of experience and thought processes with whose aid we consider as merely subjective whatever other emotional states used to delude us ... So our emotional attitude too, if it is to be adapted to reality, does not depend solely on the emotions governing us at the moment . . . but depends simultaneously on the enduring and recurrent emotional state that guarantees an understanding of reality and is usually as little visible as the air within which we breathe. ${ }^{72}$

Ulrich does not say what the relevant cool feelings are. A very good candidate is interest. (Another is attention. Musil's Doktorvater, Carl Stumpf, thought that attention was just interest.) Interest, like the other cognitive feelings, such as wonder, astonishment, and surprise, and like attention, has no opposite. This is not because it is a neutral feeling, as is surprise. Interest is a positive feeling. But it is a cool feeling because it has no opposite. It is also a feeling which can endure.

What triggers interest and attention? Often, novelty. But interest is also triggered by what seems to be intrinsically valuable for someone, for example, what he really is and may become, his vocation, his interests. ${ }^{73}$ What seems to be valuable in this way triggers attention and interestother things being equal. Of course, things are often not equal. Often enough, knowledge or the prospect of discovery is painful or disagreeable. The prospect of painful knowledge leads, as we have seen, to self-deception and ressentiment. And as any reader of The Man Without Qualities 
knows, although interest and attention may lead to the desire or will to know, they are not necessary. ${ }^{74}$

As already mentioned, Musil opposes intelligent stupidity, what I have called foolishness, to the significant:

The significant (important) unites the truth we are able to perceive in it with qualities of the feelings that give us confidence for something new: for an insight but also a resolve, for fresh perseverance, for whatever has both intellectual and emotional content and "suggests" ["zumutet"] a certain kind of conduct in ourselves or in others; this is the way it could be put; and what is more important in connection with stupidity is that the significant is accessible to criticism's understanding aspect as well as to its feeling aspect. The significant is also the common opposite of both stupidity and coarseness (brutality), and the general disproportion in which, today, emotions crush reason instead of inspiring it also merges with the notion of the significant. ${ }^{75}$

The significant here is perhaps just the valuable. In the writings of both the phenomenologists and the Gestalt psychologists value is said to require or motivate or demand (fordern) reactions of different types. Musil says that the significant "suggests" kinds of conduct. Musil's view seems to be that awareness of (apparent) value is opposed to stupidity of the higher kind because such awareness typically triggers interest and so epistemic desires. ${ }^{76}$

What, if anything, works against foolishness? Musil's answer is that "the ... most important weapon against stupidity [is]: modesty [Bescheidung]." 77 His elaboration of this claim is to be found in his (incomplete) account of the utopia of inductive humility.

Wisdom, it is often asserted, is the or an opposite of foolishness. Musil concludes "On Stupidity" as follows:

... I declare myself in no position to go further; for one step beyond the point at which we are stopping and we would leave the realm of stupidity which even theoretically has an extraordinary variety, and would arrive in the realm of wisdom, a desolate [öde] region that is generally shunned. ${ }^{78}$

Should wisdom be shunned in a philosophy of foolishness? If foolishness is indifference or hostility towards cognitive values, then Pan-Romantics and Postmodernists preach foolishness and, if they are not hypocrites, are fools. Is, then, wisdom a function of a due appreciation of such values? The affirmative answer to this question turns cognitive values into ideals, a way of 
speaking sometimes endorsed by Musil, as we have seen. There is an alternative answer which avoids treating cognitive values as ideals: wisdom is just the absence of foolishness. This view resembles such normative claims as: injustice is the absence of justice, health is the absence of illness, grammaticality is the absence of ungrammaticality; and also such nonnormative claims as that reality is the absence of illusion. Of the two, foolishness and wisdom, it is the former which wears the trousers. ${ }^{79}$

Musil's explorations of foolishness are part of the fabric of his novel, part of its "immanent philosophy"- a term he employs when comparing Beyle and Brontë (Charlotte) ${ }^{80}$ Just how they function aesthetically is a question not even touched upon here. His explorations are part of his struggle against foolishness and of his effort to say something new about it: "Where art has value it shows things that few have seen." 81 One type of knowledge fiction may provide is of the noncontingent connections between values of different types and what makes their bearers valuable, their "valifiers." 82 Great works of fiction, it seems to me, point to new value-makers for old values more often than to the new values Nietzsche and his followers dream of. Musil extends our knowledge of what sorts of thing may make someone exemplify the cognitive disvalue of foolishness in ways that go well beyond Flaubert's pioneering efforts in the same direction. ${ }^{83}$

Kevin Mulligan

University of Geneva

\section{Notes}

1. Ortega $2000,123$.

2. Musil 1995a, 1760.

3. Musil 1983, 894.

4. Bouveresse 2001, 189-226.

5. Musil 1988, III, 218.

6. Musil 1988, III, 328.

7. Musil 1983a, I, 557.

8. Musil 1995, I, 10.

9. Musil 1995, I, 11 .

10. Musil 1995, I 10.

11. According to the first but not the second epistemic utopia, thoughts are necessarily impersonal. Cf. Krämer $(2009,133)$.

12. Musil's essay has, of course, some political targets. Cf. Corino (2003, 1228-39). 
13. Cf. Engel (2012).

14. Cf. Vatan (1991). On Musil on foolishness and culture, cf. Imhoof (2009).

15. Scheler $1976,137$.

16. Lessing 1927, 28; Scheler 1976, 65.

17. Cf. Mulligan (2006), which also indicates some of the many differences between the philosophies of Musil and Scheler.

18. Musil 1988, I, 219.

19. Musil 1983a, I, 429.

20. Musil 1983a, I, 398.

21. Musil 1983a, I, 540, my emphasis-KM.

22. Musil 1995, I, 588-89, my emphasis-KM.

23. Musil 1988, II, 292.

24. Musil 1988, II, 104-105, my emphasis-KM.

25. Musil 1995, I, 304.

26. Blei $1940,20$.

27. Musil 1988, II, 105.

28. Musil 1983a, I, 540.

29. Musil 1995, I, 596.

30. Musil 1995, I, 597.

31. Cf. Mulligan (2008).

32. Musil 1995, I, 650.

33. Musil 1990, 132.

34. Musil 1990, 38-39.

35. Musil 1978, GW 7, 898-99, cf. 880.

36. Musil 1990, 56.

37. Cf. Mulligan (2009).

38. Musil 1995, I, 265; on this passage, cf. Bouveresse (2001, 364).

39. Musil 1995, I, 265.

40. Musil 1995, I, 265.

41. Musil 1990, 107. Cf. Scheler (1963, 132-33).

42. Musil 1990, 106-107, scare quotes introduced by translator; emphasis mine-KM.

43. Musil 1990, 107.

44. Musil 1983b, 313.

45. Musil 1995, I, 198.

46. Shaw's (1960 [1891]) The Quintessence of Ibsenism anticipates in remarkable detail Musil's critique of ideals.

47. Musil 1978, GW 7, 1343-44.

48. Musil 1995, 198.

49. Musil 1995, I, 198-99, first emphasis mine-KM.

50. Musil 1978, GW 5, 1635.

51. Musil 1978, GW 4, 1458.

52. Musil 1978, GW 5, 1845.

53. Musil 1978, GW 4, 1458; GW 5, 1634-45. Unlike Meingast, Ludwig Klages deifies neither ideals nor the will.

54. On Lindner, cf. Bouveresse (2001, 358-71, esp. 358-59).

55. Musil 1990, 54.

56. Musil 1995, II, 1142.

57. Musil 1995, II, 812. 
58. Musil 1995, II, 1145.

59. Musil 1995, II, 1145-46, emphasis mine-KM.

60. Musil 1995, II, 1135.

61. Musil 1995, II, 1749. Cf. Aspetsberger (1980).

62. Musil 1978, GW 4, 1317; cf. GW 8, 1397.

63. Musil 1995, II, 792-33.

64. Musil 1995, I, 199. Living For and ideals are essential to maintaining affective equilibria, a phenomenon at the heart of Musil's anatomy of emotions (cf. Krämer [2009, 135]). Musil's account of such equilibria draws on the well-known views of the Berlin Gestalt psychologists.

65. Musil 1978, GW 4, 1459, 1461; GW 5, 1871.

66. Musil 1978, GW 5, 1635.

67. Musil 1978, GW 8, 1272.

68. Musil 1990, 282.

69. Musil 1990, 283-84; Musil is here quoting from $\mathrm{ch} .16$ of his novel. On the distinction between the two types of stupidity cf. Musil (1995, I, 37; Musil 1978, GW 8, 1221).

70. Musil 1990, 268.

71. Musil 1990, 267.

72. Musil 1995, II, 1299-300, translation modified, emphases mine-KM.

73. Cf. Mulligan (2009).

74. Cf. Musil (1995, I, ch 72).

75. Musil 1990, 286, translation modified.

76. Cf. Mulligan (2009a). In 1913 Musil put forward the very interesting suggestion that ethical goodness and evil, like beauty and ugliness, are not opposites (Musil 1990, 38). Did he perhaps give up his earlier view?

77. Musil 1990, 286.

78. Musil 1990, 286.

79. As they stand, such formulations are clearly inadequate. First, tables are neither ill (foolish) nor healthy (wise). Perhaps, then, we should say that to be healthy is to be not ill and the sort of thing which in virtue of its nature can be ill. Second, claims to the effect that of two axiological terms one wears the trousers should come with some account of axiological indifference.

80. Musil 1983, 316. On Stendhal and Musil, cf. Lombardo (2009).

81. Musil 1990, 7.

82. The claim that fiction is a source of knowledge about contingent facts about human psychology has become very unpopular due to empirical work sceptical of the reality of character. Musil anticipated very thoroughly such scepticism about character, although unlike many psychologists he is less sceptical about enduring attachments and sentiments.

83. Cf. Vatan (2009).

\section{REFERENCES}

Aspetsberger, Fr. 1980. "Anderer Zustand, Für-In," in Baur, U. and Castex, E., eds., Robert Musil. Untersuchungen, Königstein: Athenäum, 46-66.

Blei, F. 1940. Zeitgenössische Bildnisse, Amsterdam: Allert de Lange. 
Bouveresse, J. 2001. La Voix de l'âme et les chemins de l'esprit. Dix études sur Robert Musil, Paris: Seuil.

Corino, K. 2003. Robert Musil. Eine Biographie, Reinbek: Rowohlt.

Engel, P. 2012. Les lois de l'esprit, Julien Benda ou la raison, Paris: Ithaque.

Imhoof, St. 2009. "Kultur und Dummheit: Eine Analyse der Wiener und Pariser Reden von Robert Musil als Dyptichon," in Mulligan and Westerhoff, eds. (2009, 75-98).

Krämer, O. 2009. Denken erzählen: Repräsentationen des Intellekts bei Robert Musil und Paul Valéry, Berlin: de Gruyter.

Lessing, Th. 1927. Geschichte als Sinngebung des Sinnlosen, Leipzig: Reinicke Verlag.

Lombardo, P. 2009. "Musil, Stendhal und die Dynamik der Gefühle," in Mulligan and Westerhoff, eds. (2009, 125-48)

Mulligan, K. 2006. "Geist (and Gemüt) vs Life-Max Scheler and Robert Musil," Le Ragioni del Conoscere e dell'Agire. Scritti in onore di Rosaria Egidi, ed. R. Calcaterra, Milan: Franco Angeli, 366-78.

- 2008. "Ironie, valeurs cognitives et bêtise," Philosophiques 35 (1), Les valeurs de l'ironie, ed. P. Engel, 89-107.

. 2009. "Selbstliebe, Sympathie, Egoismus," in Mulligan and Westerhoff, eds. $(2009,55-73)$.

- 2009a. "Torheit, Vernünftigkeit und der Wert des Wissens," Wissen und Werte, ed. G. Schönrich, Paderborn: mentis Verlag, 27-44.

Mulligan, K. and A. Westerhoff, eds. 2009. Robert Musil-Ironie, Satire, falsche Gefühle, Paderborn: mentis Verlag.

Musil, R. 1978. Gesammelte Werke, 9 volumes, ed. A. Frisé, Reinbek: Rowohlt

- 1983. Tagebücher, ed. A. Frisé, Reinbek: Rowohlt.

. 1983a. Der Mann ohne Eigenschaften, 2 volumes, ed. A. Frisé, Reinbek: Rowohlt.

. 1983b. Prosa und Stücke. Kleine Prosa. Aphorismen. Autobiographisches, ed. A. Frisé, Reinbek: Rowohlt.

- 1988 The Man Without Qualities, 3 volumes, trans. E. Wilkins and E. Kaiser, London: Picador.

- 1990 Precision and Soul. Essays and Addresses, ed. and trans. B. Pike and D.S. Luft, Chicago and London: University of Chicago Press.

- 1995 The Man Without Qualities, 2 volumes, trans. S. Wilkins and B. Pike, London: Picador.

Ortega y Gasset, J. 2000. La Rebelión de las masas, Madrid: Alianza.

Scheler, M. 1963. Schriften zur Soziologie und Weltanschauungslehre, Gesammelte Werke 6, ed. M. Frings, Bern: Francke.

1976, Späte Schriften, Gesammelte Werke 9, ed. M. Frings, Bern: Francke.

Shaw, G.B. 1960 (1891). The Quintessence of Ibsenism, New York: Hill and Wang.

Vatan, F. 1991. "De la bêtise," Europe. Revue littéraire mensuelle 69, 741-42, 54-61.

—. 2009. "Flaubert, Musil und der Reiz der Dummheit," in Mulligan and Westerhoff, eds. $(2009,149-72)$. 